原著 降圧剤治療を受けている 50 歳代男性労働者 における脳心事故の危陨因子

内山集 二*1, 倉 沢高 志汭, 関 沢 敏 弘*3

中 塚 比呂志*4

\title{
RISK FACTORS OF CEREBRO-CARDIOVASCULAR EVENTS IN TREATED HYPERTENSIVE MALE WORKERS IN THE FIFTH DECADE
}

\author{
Shuji Uchiyama, ${ }^{* 1}$ Takashi KuRASAWA, ${ }^{* 2}$ Toshihiro Sekizawa*3 \\ and Hiroshi NAKATSUKA ${ }^{* 4}$
}

\begin{abstract}
The relationship between cerebro-cardiovascular events (CCE) and work-related factors was examined in a cohort of 899 treated hypertensive men who were aged 50-59 yr and working more than 7 portal to portal hours ( $\mathrm{PPH})$. During the follow-up of $2.8 \mathrm{yr}(2,513$ person-years), 27 cases of CCEs occurred, which were classified into 18 cases of stroke, 7 cases of acute myocardial infarction, and 2 cases of others. Using univariate analysis, it was found that managerial position and long PPH (more than $11 \mathrm{~h}$ ) were significantly related to CCE (relative risk of 3.0 and 2.2, respectively) as well as risk factors such as emaciation, left ventricular hypertrophy, excessive sleeping hours, obesity, cigarette smoking, and inadequate control of systolic blood pressure. Using Cox proportional hazards general model, both managerial position and long PPH remained independently related to the risk of $\mathrm{CCE}$ (hazards ratio and $95 \%$ confidence interval, $4.1 ; 1.7-10.0$ and 2.7 ; 1. 1-6.2, respectively), after adjustment for other risk factors. These findings suggested that work-related factors, such as managerial position and long PPH, are independent risk factors of $\mathrm{CCE}$ among treated hypertensive male workers in the fifth decade.
\end{abstract}

Key words: hypertensive worker; follow-up study; cerebro-cardiovascular event; risk factor; work-related factor; working hour; managerial position

\section{I.はじめに}

過重な労働負担が誘因となって高血压や動脈硬化など の基礎にある疾患を悪化させ，脳血管疾患や虚血性心疾 患, 急性心不全などを発症し, 死に至らせる事例は, 「過労死」と呼ばれて社会的関心を集めている1,2). WHO も，高血圧や心疾患などを労働関連疾病（work-

*1 南医療生協星崎診療所

*2 又なと生協診原所

*8 葵会北病院

*4 西腚病院 平成 3 年 2 月 9 日受付

*1 Hoshizaki Clinic, Minami Medical Co-op

*2 Minato Seikyo Clinic

*8 Kita Hospital, Aoikai

*4 Nishiyodo Hospital Received for publication, February 9, 1991 related disease) として位置づけ，労働との関連を強調 している゙．しかし，日本では，労働関連疾病は「過労 死」も含めて関心が高まっているが，実態の把握や因果 関係の研究は緒についたばかりである4．そこで，われ われは，現役労働者で最も脳血管疾患や心疾患の発症の 多い世代である 50 歳代男性の高血圧患者について，労 働因子之脳心事故の発症の関連性について前向き調査か ら検討した。

\section{II. 対象と方法}

全日本民主医療機関連合会の全国 123 の医療機関で棈 成する高血圧追跡調查会において，1985 年から88 年の 間に，降圧剤服薬者で， 1 年以上通院し，脳卒中，心筋 梗塞, うっ血性心不全, 慢性腎不全や癌がなく、ステロ イト，インスリン剂未使用で，かつ 40 75 歳に該当す 
るものを，合計 8,394 人登録した. 本研究の対象は，こ れらの登録者の中の, 50 59 歳の男性で 1 日拘束時間 7 時間以上の 923 人である. 40 歳代を対象から除外した のは, 40 歳代の発症者が 8 人で統計的解析飞は発症数か 少なかったためであり，60歳代を除外したのは，定年退 職，高秢者としての再就職の世代であり労働との関連で は 50 歳代とは同一に論じられないためであった．登録 時に，体重，身長，安静坐位血圧值を測定し，生活と労 働に関する事項は医師または看護婦が一定の問診表に基 つ゚いて聴取した. さらに，外来カルテより，過去 1 年間 の3か月ごとの血压值, 半年内の心電図, および血清コ レステロール值を調ベた，登録者の脳血管疾患拈よび心 疾患の発症，生死を調べるために，登録した時点から 1 年ごとにカルテの点検と本人へのアンヶート，死亡した 場合は家族へのアンケートを1986 年から1990 年にわた って実施した。 未受診の者や転居した者には電話や手紙 で消息を確認した．また，脳血管疾患や心疾患の発症が あった場合には経過や診断根拠を調べた。本研究では， これらのうち, 脳出血, 脳梗塞, 脳塞栓, 病理診断不明 の脳卒中, 〈子膜下出血, 心筋梗塞, 心不全, 大動㭽瘤 破裂，突然死の 9 病名を脳心事故之定義した．脳心事故 の発症率は人年法で求めた。観察期間は 1 年単位とした が，腷心事故発症のあった調查年度は 0.5 年として計算 したまた，登録時にどのような因子をるっていた者に 脱心事故が多かったかを険討するために，登録時の調查 票から以下の因子を定義した． 1 日拘束時間 11 洔間以 上を「長時間拘束」，6人以上の企業の部長以上の職を 「管理職」, 2 週間に 1 日以下の休日を「少ない休日」, 仕 事や職場のことでストレスのたまることが「よく西る」, 「時々ある」を「仕事のストレス感あり」，午後 10 時か ら翌朝午前 5 時の間の仕事を「深夜労働」とした，睡眠 時間は 9 時間以上を「長い陲眠」，6時間以下を「短い 睡眠」とし，7〜8時間を対照とした．起床時の「疲れ ている」「非常に疲九ている」を「朝の疲労感あり」と したばこは「吸っている」を「典㖶あり」とし，「吸 わない」「止めた」を対照とした. フルコールは日本酒 に換算して1日2合以上を「领酒あり」とした．血圧值 は，カルテに記載された過去 1 年間の 3 か月ごとの血圧 值之登録時の血圧値の計 5 回の平均値で評価し, 収縮期 血圧は $140 \mathrm{mmHg}$ 末満, $140 \sim 159 \mathrm{mmHg}, 160 \mathrm{mmHg}$ 以上飞分け $160 \mathrm{mmHg}$ 以上を「収縮期血圧管理不良」 とした. 拡張期血压は $80 \mathrm{mmHg}$ 未満, $80 \sim 94 \mathrm{mmHg}$, $95 \mathrm{mmHg}$ 以上に分け，95 $\mathrm{mmHg}$ 以上を「払張期血压 管理不良」とした．肥満度は Body Mass Index（体重 $(\mathrm{kg}) /$ 身長 $(\mathrm{m})^{2}$, 以下 BMI と略) で求め, 20 末満を
「やせ」，28以上を「肥満」，20.0〜27.9を対照とした。 心電图は東大 3 内科分類基準5て心肥大または ST-T 変 化のあるるのを「心肥大， ST-T 変化あり」とし，どち らでるないすのを対照とした，血清総コレステロールは $240 \mathrm{mg} / \mathrm{dl}$ 以上を「コレステロール高值」とし 160 $239 \mathrm{mg} / \mathrm{dl}$ を対照とした. 以上のらち，対照の記載して いない因子は，因子に該当しないものを対照とした。こ れらの因子あり群と対照群で別々に脳心事故発症率を求 め，その比を相対危険度とした．また，これらの因子間 のPeasonの相関保数を求めた．長時間拘束群之対照群 の諸因子保有率の美は正規分布の統計量 $\boldsymbol{z}$ 值に上り両側 検定を行った，多変量解析による相対危险度は， $\mathrm{SAS}^{6}$ ) を使って Cox の比例ハザードモデルで求めた.

III. 結果

\section{1. 追跡秸果}

本研究の対象者 923 人中, 追跡できたるのは 899 人 で，追跡率は $97.4 \%$ であった．追跡のできた 899 人に ついて解析した．観察期間は，2,512.5 人年， 1 人平均 2.8 年であった。観察期間内に, 脳出血 4 人, くも膜下 出血 2 人 ( 1 人死亡), 脳梗塞 12 人, 心筋梗塞 7 人 ( 2 人死亡)，心不全 1 人，動脈齄破裂 1 人（死亡）の計 27 人（うら死亡 4 人） に初回の脳心事故発症があった，27 人のうち， 22 人は頭部 CT や心電图の異常 $\mathrm{Q}$ 波など確 実な診断根拠によるものであり，残りの 5 人注䎐居，転 院などのため病名を確認したのみで，診断根扰住確かめ られなかった。脳血管疾患は脳心事故の $67 \%$ を占めた。 発症率は 1,000 人年当たり 11 人, 死亡率は脳心事故の 中の $15 \%$ であった，発症者の一覧を Table 1 に示した。

\section{2. 諸因子の相対危険度 (単変量解析)}

登録時にどのような因子をるっているものに脳心事故 が多かったが相対危険度で検討し，結果を Table 2 に 示した．労働に関連した因子の中で，相対危険度が有意 に高かったものは，「管理職」の 3.0，「長時間拘束」の 2.2 の 項目であった.「少ない休日」は2.1 と高い相 対危険度を示したが統計学的には有意差はなかった，そ の他の問診項目では，「長い棰眠」が 3.3 と有意汇高值 を示した、「揳原あり」、「朝の疲労感あり」も有意差は なかったがそそれぞれ 1.9,1.8 と高い値を示した. 検 查項目で相対危険度が有意に高かったるのは，「やせ」， 「肥満」, 「心肥大, ST-T 变化あり」の各因子で, 相対 危険度はそれぞれ 5.7，3.3，2.7であった。また，収縮 期血圧は 140 159 mmHg を対照として, $140 \mathrm{mmHg}$ 未满群は 2.0 $160 \mathrm{mmHg}$ 以上の「収縮期血王管理不 良」群は3.6で, 後者は有意に高かった。捘張期血圧は 
Table 1. Characteristics of 27 workers who had cerebro-cardiovascular events during the follow-up period involving 2,513 person-years in 899 treated hypertensive male workers in the fifth decade $1985-1990$, at 123 clinics in Japan.

\begin{tabular}{|c|c|c|c|c|c|c|c|c|c|c|c|c|c|}
\hline No. & Occupation & 品 & 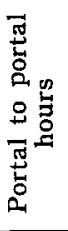 & 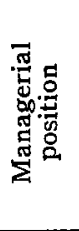 & 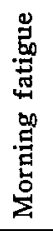 & 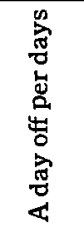 & $\begin{array}{l}\text { 品 } \\
\text { 总 } \\
\text { 号 }\end{array}$ & 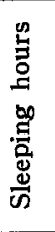 & 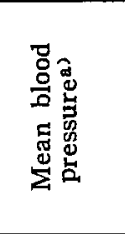 & 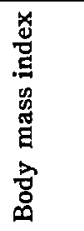 & 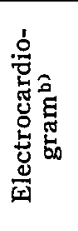 & 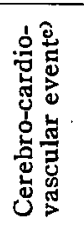 & 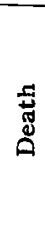 \\
\hline 1 & Administrator & 54 & 7 & + & & $1 / 7$ & + & 9 & $134 / 80$ & 28.4 & 0 & $\mathrm{CI}$ & \\
\hline 2 & Administrator & 59 & 8 & + & & $1 / 7$ & + & 9 & $136 / 84$ & 19.5 & 0 & AMI & + \\
\hline 3 & Taxi driver & 57 & 8 & & & $1 / 4$ & + & 8 & $167 / 111$ & 24.5 & 2 & $\mathrm{AR}$ & + \\
\hline 4 & Electrical engineer & 50 & 8 & & & $1 / 7$ & + & 4 & $132 / 97$ & 22.4 & 0 & $\mathrm{SAH}$ & \\
\hline 5 & Unknown & 53 & 8 & & + & $1 / 5$ & + & 5 & $160 / 103$ & 18.0 & 0 & AMI & \\
\hline 6 & Reporter & 54 & 8 & & + & $1 / 7$ & & 8 & $139 / 90$ & 26.3 & 0 & ICH & \\
\hline 7 & Door keeper & 55 & 8 & & & $1 / 7$ & & 9 & $141 / 89$ & 22.5 & 2 & $\mathrm{CI}$ & \\
\hline 8 & Iron and steel worker & 58 & 8 & & & $1 / 7$ & + & 8 & $172 / 97$ & 19.4 & 1 & $\mathrm{CI}$ & \\
\hline 9 & Electical engineer & 58 & 8 & & + & $1 / 7$ & & 6 & $154 / 94$ & 26.5 & 1 & AMI & \\
\hline 10 & Printer & 58 & 8 & & & $1 / 6$ & + & 8 & $156 / 94$ & 17.3 & 1 & $\mathrm{CI}$ & \\
\hline 11 & Delivery man & 51 & 8 & & & $1 / 7$ & & 9 & $139 / 90$ & 29.2 & 0 & $\mathrm{CI}$ & \\
\hline 12 & Tailor & 54 & 8 & & + & $1 / 7$ & + & 10 & $169 / 109$ & 20.0 & 1 & $\mathrm{CI}$ & \\
\hline 13 & Clerical worker & 54 & 9 & & & $1 / 7$ & & 7 & $162 / 92$ & 24.4 & 1 & $\mathrm{ICH}$ & \\
\hline 14 & Clerical worker & 52 & 9 & & & $1 / 7$ & + & 6 & $166 / 100$ & 30.2 & 2 & $\mathrm{CI}$ & \\
\hline 15 & Stone mason & 57 & 9 & & + & $1 / 7$ & + & 8 & $155 / 97$ & 21.1 & 1 & $\mathrm{ICH}$ & \\
\hline 16 & Clerical worker & 51 & 9 & & & $1 / 7$ & & 8 & $134 / 88$ & 21.2 & 0 & AMI & \\
\hline 17 & Farmer & 53 & 10 & & & $1 / 7$ & + & 9 & $122 / 79$ & 20.6 & 0 & CI & \\
\hline 18 & Administrator & 57 & 10 & + & & $1 / 7$ & & 8 & $146 / 96$ & 29.7 & 0 & $\mathrm{CI}$ & \\
\hline 19 & Construction worker & 52 & 10 & & + & $1 / 15$ & + & 7 & $144 / 86$ & 22.5 & 2 & $\mathrm{SAH}$ & + \\
\hline 20 & Administrator & 50 & 11 & + & & $1 / 7$ & + & 7 & $138 / 82$ & 19.6 & 2 & $\mathrm{ICH}$ & \\
\hline 21 & Clerical worker & 54 & 12 & & + & $1 / 7$ & + & 8 & $145 / 96$ & 20.7 & 0 & $\mathrm{CI}$ & \\
\hline 22 & Auto mechanic & 55 & 12 & & + & $1 / 7$ & + & 10 & $167 / 104$ & 29.0 & 2 & AMI & \\
\hline 23 & Restaurateur & 58 & 12 & + & & $1 / 7$ & + & 8 & $155 / 88$ & 25.0 & 1 & $\mathrm{CHF}$ & \\
\hline 24 & Administrator & 57 & 12 & + & + & $1 / 60$ & + & - & $137 / 81$ & 21.3 & 0 & $\mathrm{CI}$ & \\
\hline 25 & Painter & 52 & 12 & & + & $1 / 15$ & + & 6 & $136 / 92$ & 20.0 & 1 & $\mathrm{CI}$ & \\
\hline 26 & Teacher & 56 & 13 & & & $1 / 16$ & + & 4 & $137 / 81$ & 24.0 & 0 & AMI & + \\
\hline 27 & Administrator & 52 & 14 & + & & $1 / 30$ & & 6 & $150 / 88$ & 24.1 & 1 & AMI & \\
\hline
\end{tabular}

a) Treated mean blood pressure refers to the mean of five readings taken at the time of entry, b) 0 : non left vetricular hypertrophy and non ST-T change, $1:$ left ventricular hypertrophy, $2:$ ST-T change. c) ICH : intracerebral hemorrhage, CI : cerebral infarction, SAH : subarachnoid hemorrhage, AR : aortic anuerysmal rupture, AMI : acute myocardial infarction, $\mathrm{CHF}$ : congestive heart failure.

80 95 mmHg を対照として, $80 \mathrm{mmHg}$ 未満群は 0.6, $95 \mathrm{mmHg}$ 以上群は 1.5 で, どの群間にる有意差はなか っだ. 労働因子の中で, 有意に相対危険度の高かった 「管理職」群と，「長時間拘束」群について，その特徵 を以下に検討した。

\section{3. 労俾生活因子相互の相関}

学働因子と生活因子は相互に関連していると考えられ るので，相対危険度の高かった「長時間拘束」，「管理 職」、「少ない休日」,「短い睡眠」，「長い睡眠」，「朝の疲 労感あり」の6 項目について相互の相関係数を調べた. 
Table 2. Relative risks of risk factors by univariate analysis.

\begin{tabular}{|c|c|c|c|}
\hline Risk factor (case : control) & $\begin{array}{l}\text { Person-years } \\
\text { (case : control) }\end{array}$ & $\begin{array}{c}\text { Incidence } \\
\text { per } 1,000 \\
\text { person-years } \\
\text { (case : control) }\end{array}$ & $\begin{array}{c}\text { Relative } \\
\text { risk }\end{array}$ \\
\hline Managerial post (yes : no) & $238: 1,122$ & $29.5: 9.8$ & 3. $0^{* *}$ \\
\hline Long portal to portal hours ( $\geq 11 \mathrm{~h}: 7-10 \mathrm{~h}$ ) & $405: 2,106$ & $19.8: 9.0$ & $2.2^{*}$ \\
\hline Few days off $(<1 / 14 \mathrm{~d}: \geqq 1 / 14 \mathrm{~d})$ & $216: 1,639$ & $23.2: 11.0$ & 2.1 \\
\hline Work stress (yes : no) & $1,755: 1,866$ & $8.6: 8.0$ & 1.1 \\
\hline Excessive sleeping hours ( $\geqq 9 h: 7-8 h)$ & $285: 1,617$ & $24.6: 7.4$ & 3. $3^{*}$ \\
\hline Cigarette smoking (yes : no) & $1,209: 705$ & $15.7: 8.5$ & 1.9 \\
\hline Morning fatigue (yes : no) & $608: 1,869$ & $16.5: 9.1$ & 1.8 \\
\hline Short sleeping hours ( $\leqq 6 \mathrm{~h}: 7-8 \mathrm{~h}$ ) & $571: 1,617$ & $12.3: 7.4$ & 1.7 \\
\hline Emaciation $(\mathrm{BMI} a)<20: 20-27)$ & $112: 2,145$ & $44.8: 7.9$ & $5.7^{* *}$ \\
\hline Inadequate control of $\left.\mathrm{SBP}{ }^{b}\right)(\geqq 160 \mathrm{mmHg}: 140-159 \mathrm{mmHg})$ & $296: 1,386$ & $23.7: 6.5$ & $3.6^{* *}$ \\
\hline Obesity $\left.\left(B M I^{a}\right) \geqq 28: 20-27\right)$ & $194: 2,145$ & $25.8: 7.9$ & $3.3^{* *}$ \\
\hline $\begin{array}{l}\text { High voltage or ST-T changes in electrocardiogram } \\
\text { (yes: no) }\end{array}$ & $800: 1,713$ & $18.8: 7.0$ & $2.7^{* *}$ \\
\hline High serum cholesterol ( $\geqq 240 \mathrm{mg} / \mathrm{dl}: 160-239 \mathrm{mg} / \mathrm{dl}$ ) & $294: 1,766$ & $17.0: 9.1$ & 1.9 \\
\hline Inadequate control of $\mathrm{DBP})(\geqq 95 \mathrm{mmHg}: 80-94 \mathrm{mmHg})$ & $705: 1,644$ & $14.2: 9.7$ & 1.5 \\
\hline
\end{tabular}

「長時間拘束」は，「少ない休日」(相関係数 $r=0.22)$ ， 「短い睡眠」( $r=0.11)$ ，「朝の疲労感市り」( $r=0.12)$ と有意な相関が認められたが，「管理職」はこれらの因 子とはどれも相関はなかった。すた，「短い睡眠」と「朝 の疲労感あり」( $r=0.16)$ に有意な相関が，「長い睡眠」 と「朝の疲労感西り」( $r=-0.09)$ に有意な逆相関が 認められた。

\section{4. 管理職の特徽}

「管理職!は 92 人 $(10 \%)$ で，その他（対照群）は 807 人であった。管理職は対照群に比し，「仕事のスト レス感あり」(71\% vs. $53 \%)$ が有意に多く，「深夜労 働」(11\% vs. $22 \%)$ が有意に少なかった，その他，「喫 煙あり」,「血圧管理不良」「やせ」,「肥満」，「心肥大， ST-T 変化あり」などには 2 群間に有意差はなかった。

\section{5. 拘束時間別の脳心事故の頻度}

拘束時間別の発症者の頻度を Table 3 に示した. 10 時 間以下では，どの時間群む発症頻度は $3 \%$ 以下であった が, 11 時間から 14 時間では $4 \%$ から $10 \%$ と高かった。

\section{6. 長時間拘束群の特徽}

長時間拘束群の特徵をTable 4 と示した. 長時間拘束 群は 142 人，対照群は 757 人で，前者は全体の $16 \%$ を
Table 3. Distribution of cerebro-cardiovascular events occurring during follow-up involving 2,513 person-years in 899 treated hypertensive male workers in the sixth decade 1985-1990, at 123 clinics in Japan, according to portal to portal hours.

\begin{tabular}{crrr}
\hline $\begin{array}{c}\text { Portal } \\
\text { to portal } \\
\text { hours }\end{array}$ & No. & $\begin{array}{c}\text { Cerebro-cardiovascular } \\
\text { events (\%) }\end{array}$ \\
\hline 7 & 36 & 1 & $(3)$ \\
8 & 335 & 11 & $(3)$ \\
9 & 182 & 4 & $(2)$ \\
10 & 204 & 3 & $(1)$ \\
11 & 24 & 1 & $(4)$ \\
12 & 55 & 5 & $(9)$ \\
13 & 16 & 1 & $(6)$ \\
14 & 10 & 1 & $(10)$ \\
$\geqq 15$ & 37 & 0 & $(0)$ \\
\hline Total & 899 & 27 & \\
\hline
\end{tabular}

Cerebro-cardiovascular events included strokes, myocardial infarctions, congestive heart failures, aortic anurysmal ruptures and sudden deaths. 
Table 4. Work-related and clinical characteristics compared with and without long portal to portal hours.

\begin{tabular}{|c|c|c|c|}
\hline Characteristic & $\begin{array}{l}\text { Long portal } \\
\text { to portal } \\
\text { hours }\end{array}$ & Control & \\
\hline No. & 142 & 757 & \\
\hline \multirow[t]{2}{*}{ Mean age (yr) } & $54.1 \pm 2.8$ & $54.7 \pm 2.8$ & NSa) \\
\hline & No. of yes $\left(\%^{b}\right)$ & No. of yes $(\%$ b) $)$ & \\
\hline Midnight work & $60(46)$ & $113(16)$ & $* *$ \\
\hline Few days off $(<1 / 14 \mathrm{~d})$ & $40(32)$ & $73(11)$ & $* *$ \\
\hline Short sleeping hours $(\leqq 6 \mathrm{~h})$ & $45(32)$ & $161(22)$ & $* *$ \\
\hline Morning fatigue & $52(37)$ & $173(23)$ & $* *$ \\
\hline Work stress & $89(64)$ & $397(53)$ & $*$ \\
\hline Managerial position & 21 (19) & 71 (11) & * \\
\hline Excessive sleeping hours $(\geqq 9 \mathrm{~h})$ & $10(7)$ & $83(11)$ & NS \\
\hline Cigarette smoking & $71(50)$ & $367(49)$ & NS \\
\hline Alcohol consumption ( $\geqq 2$ go per day) & $23(20)$ & $137(20)$ & NS \\
\hline Obesity (BMIc) $\geqq 28)$ & $11(8)$ & $58(8)$ & NS \\
\hline Emaciation $(\mathrm{BMI}<20)$ & $5(3)$ & $37(5)$ & NS \\
\hline Inadequate control of $S B P d)(\geqq 160 \mathrm{mmHg})$ & $13(9)$ & $92(12)$ & NS \\
\hline Inadequate control of $\mathrm{DBP}{ }^{\ominus}$ ( $\left.\geqq 95 \mathrm{mmHg}\right)$ & $44(31)$ & $208(27)$ & NS \\
\hline High serum cholesterol $(\geqq 240 \mathrm{mg} / \mathrm{dl})$ & $20(18)$ & $82(13)$ & NS \\
\hline High voltage or ST-T changes in ECGr) & $45(32)$ & $256(34)$ & NS \\
\hline
\end{tabular}

a) NS : not significant, b) \%:\% to respondents, c) BMI : body mass index, d) SBP : treated systolic blood pressure, e) DBP : treated diastolic blood pressure, f) ECG : electrocardiogram. ${ }^{*} p<0.05,{ }^{* *} p<$ 0.01 significantly higher percentage than control.

占めた．両群に年柃の差はなかった，職業は，全体では 生産工程作業者, 管理的職業從事者, 運輸通信従事者, 肘売従事者, 専門的技術的職業従事者, 事務従事者の順 に多く、これらで全体の 79\%のを占めだ両群に職業分 類で有意差はなかった. 一方, 「深夜労働」「少ない休 日」，「短い睡眠」，「朝の疲労感あり」，「仕事のストレス 感あり」「管理職」など, 労働と関連した諸因子が長時 間拘束群で有意に高率であった。しかし，「知凐あり」 「领酒あり」,「やせ」,「肥渾」,「血压管理不良」,「コレ ステロール高值」「心肥大, ST-T 变化あり」などには 2 群間で有意差はなかった.

\section{7. 比例ハザート゚モデル（多变量解析）}

$\operatorname{Cox} の$ 比例ハザードモデルに, 事故変数として譄心事 故発症の有無を，観察期間として人年法で用いた観察年 を, 予後因子として単変量解析で相対危険度の有意に高 かった「管理職」,「長時間拘束」,「長い睡眠」,「やせ」, 「肥満」,「収縮期血圧管理不良」, 「心肥大, ST-T 変化
あり」の 7 因子に「契煙あり」を加えた 8 因子を組み込 み, 各因子の脳心事故発症に対する寄与の程度を検討し た. なお，本追跡調査の 50 歳から 75 歳の全体を対象と した別の研究において7，架煙は有意な脳心事故の危険 因子であったので本解析の予後因子のIつに㗐煙あ り」を加学た.これら8 变数の中で，「叹縮期血圧管理 不良」と「心肥大, ST-T 変化あり」の間に弱い相関 ( $r=0.11)$ が認められたが，他の因子間では有意な相 関はなかった. ステップワイズ法による結果は Table 5 に示すようにハザード比（他の因子の影響を補正した檤 心事故発症の相対危険度）が有意に高かった因子は，高 い順に，「やせ」(7.8)，「管理職」(4.1)，「心肥大, STT変化あり」(3.7), 「長い睡眠」(3.3), 「肥満」(3.3), 「長時間拘束」(2.7)，「鿄煙あり」(2.4)の7項目であ った. 
Table 5. Hazards ratios of risk factors for cerebro-cardiovascular events occurring during follow-up period involving 2,513 person-years in 899 treated hypertensive male workers in the fifth decade 1985-1990, at 123 clinics in Japan. Results of stepwise proportional hazards general model.

\begin{tabular}{llccc}
\hline \multicolumn{1}{c}{ Risk factor } & Beta & $\begin{array}{c}\text { Standard } \\
\text { error }\end{array}$ & $\begin{array}{c}\text { Hazards } \\
\text { ratio }\end{array}$ & $\begin{array}{c}95 \% \text { confidence } \\
\text { interval }\end{array}$ \\
\hline Emaciation (BMIa) $\leqq 20)$ & 2.05 & 0.52 & 7.8 & $2.8-22.1$ \\
Managerial position & 1.41 & 0.45 & 4.1 & $1.7-10.0$ \\
High voltage or ischemic ST-T changes in ECG & 1.29 & 0.41 & 3.7 & $1.6-8.2$ \\
Excessive sleeping hours & 1.20 & 0.45 & 3.3 & $1.4-8.1$ \\
Obesity (BMIa) $\geqq 28$ ) & 1.20 & 0.51 & 3.3 & $1.2-9.1$ \\
Long portal to portal hours & 0.97 & 0.42 & 2.7 & $1.1-6.2$ \\
Cigarette smoking & 0.87 & 0.42 & 2.4 & $1.0-5.5$ \\
\hline
\end{tabular}

a) BMI : body mass index.

\section{IV. 考察}

WHO は学働関連疾病（work-related disease）の定 義と管理に関する専門委員会報告3) の中で, 職業病 (occupational disease) とは区別して，労働関連疾病を定 義し，その疾患が労働者の中で増えていることを指摘し ている. 労働関連疾病には発症に多因子が関与する高血 王や虚血性心疾患が含れれ，これらの疾患では労働に関 連した負荷も原因の1つになるとしている.WHOは， 労働に関連した負荷として，(1)労働過重（量的に多すぎ る、または質的に難しすぎる)，(2)仕事が少なすぎる， (3)変則勤務，(4)移民，(5)組織の中での役割，仕事の競争， (6)昇進の 6 項目を指摘し，疾病と労働との関連の一層の 解明を求めている。

本研究は，前向き調查から，高血圧治療を受けている 50 代男性患者において管理職と長時間拘束は脳心事故 発症の独立した危険因子である可能性を示した。本研究 の「管理職」は，調查に参加した医療機関の受診者の分 布から推察して，汇とんどが中小企業の管理職者である と考えられる.「管理職」は対照と比較して「仕事のス トレス感」が多く，「深夜労働」の少ない集団であった が，拘束時間については有意差はなかった。しかし，管 理職者は通常の拘束時間といら概念以外にも，公私にわ たって仕事に関わっている時間が多いと思われ，実質的 注長時間拘束群となっている可能性がある..一方, 長 時間拘束群には，「少ない休日」，「朝の疲労感あり」, 「深夜労働」，「仕事のストレス感あり」，「短い睡眠」が 対照群に比較して有意に多く、諸々の労働の負荷が重複 していた.このことは, 長時間拘束は量的な指標である ばかりでなく，質的な面む含めた総合的な労働過重の指
標になりうることを示唆した。

労働に関連した負荷が心疾患の危険因子であることを 示唆した研究は少なくない.たと齐ば，Ruberman ら8 は，心筋梗塞の予後調查で「生活ストレス」のあるすの に有意に死亡率が高いことを示した.この「生活ストレ ス」の定羲には「仕事がおるしろくない」が含まれてい た.ロンドンの公務員の追跡調查をした Whitehall 研 究9)は, 単純労働者は専門職者に比し心臓死が 3.6 倍多 いことを示した．この職業性因子は，血圧，偰煙，肥湍 度などよりる相対危険度が高く、また，これら既知の危 険因子だけでは職業の違いによる心臓死の差は説明でき なかった，Rabkin ら ${ }^{103} は ，$ 休日あけの月曜日に突然死 が多いことを示し，休息から仕事への復帰はストレッサ 一になるとした．他方，脳卒中との関連では，仕事で身 体活動量の少ない者は心筋梗塞と同様に脳卒中の危険を 高めることを示した Salonen ら11) の研究や精神的スト レスを感じているものに媨梗塞が多いことを示した Harmsen ら ${ }^{123}$ の住民追跡研究などがある. 労働時間に 言及したものでは, 心筋梗塞群と対照群の比較研究にお いて, 週 60 時間以上の労働, 通常勤務以外の夜勤, 仕 事の欲求不満のいずれかをるつるのは, 前者で 4.6 倍多 いことを示した Russekら ${ }^{13)}$ の報告があるが，前向き調 査から労働時間と脑心事故の関連を検討した研究は少な い.この種の研究が少ない理由の Iつに, 欧米の先進国 では労働時間が短縮していることが考えられる14).

労働に関連した因子や精神的因子が脳心事故の危険を 高める病態生理としては過去の文献から以下の3点が考 えられる、(1)高い精神的繁張や，裁量の自由度の少ない 仕事は職場での血圧を高める15)。しかも，高血圧者では 正常血圧者よりる精神的負荷に対し中枢神経系がより緊 
張しやすく16)，血肚がより上异しやすい、17)，(2)中年男性 のストレスは高へマトクリット血症を招き，高血压者に おいては脳梗塞を起こしやすい18)，(3)精神的ストレスは 虚血性心疾患の心筋壁簧常運動をきたし心駆出力を低下 させ心竻虚血を誘発する19)。(3)関連して, Lown ${ }^{20)}$ は， 心蔵病死の $60 \%$ は突然死であり，笑死には神経的緊 張が関連するとし，虚血性心疾患のあるものにおいて， 精神的刺激で心室細動が誘発されることを人の実験や臨 床例で示した．これらの諸家の報告から考えて，高血圧 や虚血性心疾患のあるものでは，労働関連因子は，作業 中の血圧上昇，血液凝固能の亢進，および心臓や血管の 生理的失調を招き，その結果として脳心事故に至ると推 察される.

本研究の多変量解析の結果では, 労働関連因子のほか に, BMI 20 未満のやせ，心電図による心肥大や ST-T 変化, 1 日 9 時間以上の長い睡眠, BMI 28 以上の肥満, および「契㾏あり」が，腷心事故の有意な危険因子であ った．睡眠との関連では，「長い睡眠」（9時間以上）は $7 \sim 8$ 時間睡眠に比して 3.3 倍の脳心事故が発症した. また，「短い睡眠」（6時間以下）む7〜8時間睡眠に比 して，1.7 倍の脳心事故が発症したが統計学的には有意 差はなかった。「短い睡眠」は，「長時間拘束」,「深夜労 働」，「朝の疲労感」と有意な相関が認められ，労働の因 子に強く関連していた，一方，「長い睡眠」は「朝の疲 労感あり」之有意な逆相関が認められたが，その他の問 診項目とは有意な相関は認められなかった。しかし，

「長い睡眠」は慢性疲労の結果とも考えられ，労動との 関連でさらに検討する必要がある，収縮期血圧について は多変量解析では有意な危険因子とならなかった，単変 量解析において収縮期血圧を，140 mmHg 未満，140〜 $159 \mathrm{mmHg}$ 群, $160 \mathrm{mmHg}$ 以上群の 3 群に分けた場合 に，中間群が一番発症率が低く，両端群で高いといら結 果になったため，多変量解析で「収縮期血王管理不良」 (160 mmHg 以上) の有無として血圧レベルを 2 分した 場合には有意差がでなかったと考えられる。また，今 回，検討した血圧值は追跡開始前の外来での平均血代値 であって，作業中や 24 時間の血圧値を示するのではな いしたがって，本結果は高血圧治療患者の血圧レベル と脳心事故発症の関連性を否定するものではないと考え

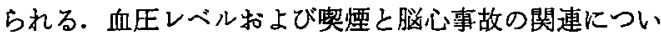
ては，別に詳しく検討した7?.

\section{V.むとめ}

1 日 7 時間以上動いている 50 歳代男性の高血圧治療 患者 899 人を平均 2.8 年, 2,513 人年追跡し，登録時の
諸因子と脳心事故発症との関連を険討した．観察期間の 中で，27人に初回の脑心事故が発症した. 18 人が脳卒 中, 7 人が心筋梗塞， 2 人はその他である. 単変量解析 では,「管理職」と「長時間拘束」（11 時間以上）は， 「やせ」,「心肥大, ST-T 变化あり」,「長い睡眠」,「肥 淽」,「哭㖶あり」,「収縮期血仕管理不良」とともに脳心 身故発症の危険因子であった，「管理職」と「長時間拘 束」は，Coxのハザードモデルを使用して他の危険因子 を補正して検討しても，脳心事故発症と関連していた。 これらの所見は，管理職や長時間拘束などの労働関連因 子は高血圧治療を受けている 50 歳代男性労働者の媨心 事故発症の独立した危険因子であることを示唆した。

本研究に助言をいたたいた名古屋大学医学部衙生学教寅，竹 内康浩教授および同教室の諸先生に感謝します。

$$
\text { 文 献 }
$$

1）上烟鉄之丞. 過労死の労働衛生学的研究. 社会医学研究 $1989 ; 8: 35-50$.

2) 阿部真雄，上烟鉄之丞. 事莱所における突然死とその予 防. 公采街生 1990；54:684-688.

3) WHO Expert Committee. Identification and control of work-related diseases. World Health Organization Technical Report Series No. 714. Geneva : World Health Organization, 1985.

4) 小沼正哉, 徳永力雄. 現代日本の労謿と健康一Workrelated Disease をめぐって一, 産業医学 $1991 ; 33$ : 605.

5）池田正男，增山善明，武田忠直，ほか，高血压症の重症 度分類（1984）一東京大学 3 内科高血圧重症度 判定基準 （1967）の改訂一. 最新医学 $1984 ; 39$ : 1213-1215.

6) SAS user's guide. Statistics. Version 5 edition. North Carolina: SAS Institute Inc, 1985.

7) Hypertension Follow-up Group of the Japan Federation of Democratic Medical Institutions. Effect of cigarette smoking on the J-shaped relationship between treated blood pressure and cardio. vascular disease. J Human Hypertens (in press).

8) Ruberman $W$, Weinblatt E, Goldberg J, et al. Psychosocial influences on mortality after myocardial infarction. N Engl J Med 1984; 311 : 552-559.

9) Rose G, Marmot M. Social class and coronary heart disease. Br Heart J 1981; 45 : 13-19.

10) Rabkin S, Mathewson F, Tate R. Chronobiology of cardiac sudden death in men. JAMA 1980; 244: 1357-1358.

11) Salonen J, Puska P, Tuomilehto J. Physical activity and risk of myocardial infarction, cerebral stroke and death. Am J Epidemiol 1982; 115: 526-537.

12) Harmsen $P$, Rosengren A, Tsipogianni A, et al. Risk factors for stroke in middle-aged men in Göteberg, Sweden. Stroke 1990; $21: 223-229$.

13) Russek $H$, Zohman B. Relative significance of heredity, diet and occupational stress in coronary 
heart disease of young adults. Am J Med Sci 1958; 235 : 266-277.

14）福島康志. 活力あるゆとり創造社会をめざして. 労働の 科学 $1989 ; 44(9): 4-7$.

15) Schnall P, Pieper C, Schwartz J, et al. The relationship between "job strain," workplace diastolic blood pressure, and left ventricular mass index. JAMA 1990; $263: 1929-1935$.

16) Schulte $W$, Neus $H$, Thones $M$, et al. Basal blood pressure variability and reactivity of blood pressure to emotional stress in essential hypertension. Basic Res Cardiol 1984; $79: 9-16$.

17) Falkner B, Onesti G, Angelakos E, et al. Cardio- vascular response to mental stress in normal adolescents with hypertensive parents. Hemodynamic and mental stress in adolescents. Hypertension $1979 ; 1: 23-30$.

18) LaRue L, Alter M, Laiet $S$, et al. Acute stroke, hematocrit, and blood pressure. Stroke 1987; 18: 565-569.

19) Rozanski A, Bairey N, Krantz D, et al. Mental stress and the induction of silent myocardial ischemia in patients with coronary artery disease. N Engl J Med 1988; 318 : 1005-1012.

20) Lown B. Role of higher nervous activity in sudden cardiac death. Jpn Circ J 1990; $54: 581-602$.

著者への通信先 : 内山集二, $\mathbf{T} 457$ 名古屋市南区星崎 1-272 星䗁診療所 Reprint requests to Hoshizaki Clinic, 1-272 Hoshizaki, Minami-ku, Nagoya, 457 Japan (S. Uchiyama) 